\title{
anatomy
}

Teaching Anatomy

www.anatomy.org.tr

Received: December 15, 2017; Accepted: February 10, 2018

doi:10.2399/ana.17.050

\section{A detailed cadaver donation form}

\author{
Sedat Develi \\ Department of Anatomy, Gïlhane Faculty of Medicine, University of Health Sciences, Ankara, Turkey
}

\begin{abstract}
Objectives: Cadavers are the basic part of anatomy education; however, the number of donations does not meet the necessity for qualified education. Donation process is regulated by laws and professional regulations. In order to avoid possible negative effects of wrong applications, it is important that the donation process should be conducted very carefully. In this study, we aimed to structure a detailed cadaver donation form for daily practice.

Methods: Responsibilities imposed by laws and regulations have been revealed by scanning the High Court jurisprudence. For application examples, a literature search in Index Medicus was made for previous studies regarding cadaver donation and ethical perspectives.

Results: In the light of regulations of laws, ethical rules and experienced legal problems a detailed consent form was structured. Conclusion: This study will contribute to donation process and provide detailed information on consent forms.

Keywords: cadaver; donation; informed consent form
\end{abstract}

Anatomy 2018;12(1):38-44 @2018 Turkish Society of Anatomy and Clinical Anatomy (TSACA)

\section{Introduction}

Anatomy is one of the branch of the basic sciences focused on human body. It is concerned with the macroscopic structures of human body. Besides other health education programs such as nursing or vocational colleges, anatomy education is a corner stone for medical education and teaching anatomy is based on cadaver training. Thus, medical education needs to be supported by sufficient number of cadavers, in order to obtain well-trained healthcare personnel.

As in other developed countries, cadaver donation is an important issue in our country and number of donations does not meet the need for qualified medical education. The legislation related to the importation and transplantation of tissues and organs is carried out within the scope of the law no. 2238, in Turkey. ${ }^{[1]}$ The 7 th article of this law gives responsibility of informing to the physician who is responsible for receiving the donation. Therefore, an informed consent form regarding cadaver donation should be submitted to the donor. The informed consent forms are extensively used for surgical procedures. Due to malpractice cases, scope of each type of consent forms expands. It is obvious that a malpractice situation about cadaver donation will affect negatively the number of donations which are already low.

In this study, we aimed to structure a detailed informed consent form for cadaver donation in the light of malpractice cases and High Court jurisprudence about organ donations and informed consent forms.

\section{Materials and Methods}

All medical procedures require the legal consent of the person to undergo medical intervention. There are two dimensions of consent forms: legal dimension described by laws and regulations, and medical dimension which regulates the ethical perspectives. ${ }^{[2]}$

In the context of the responsibilities imposed by the relevant laws and regulations, wrong applications concerning informed consent have been revealed by scanning the High Court jurisprudence. An anonymous literature search in Index Medicus was performed for previous studies regarding cadaver donation and ethical perspectives. Cadaver donation, informed consent form, malpractice, organ donation, donation ethics were the keywords used in literature search. A detailed consent form has been structured taking into account both the 
legal provisions and good application examples. This study has been carried out according to Declaration of Helsinki updated in 2013.

\section{Results}

Physicians perform their duties within the framework of legal and professional ethics regulations. Informed consent forms are part of the medicolegal process of the medical profession.

The concept of informed consent form has been existed for a long time in High Court jurisprudence. The decision of the Court dated 1977 states that the physician is responsible for informing the patient before medical interventions. ${ }^{[3]}$ The decisions taken in 2008 and 2014 also state that this information needs to be elaborated and the patient has to know what the procedure is and the patient must know how the medical process can develop. Briefly, the patient should be aware of what he/she is consenting. ${ }^{[4,5]}$ Responsibility of this issue is imposed by the relevant laws and regulations to the physician.

When the legal cases of informed consent forms were examined in the light of these regulations, these main topics were confronted:

- Inadequate or no information: especially complications are not explained in detail.

- The medical terms make it difficult to understand.

- Lack of medical documentation: verbal affirmation in the presence of witnesses is not sufficient.

In the light of regulations of laws, ethical rules and experienced legal problems, the cadaver donation form should be given by the physician including detailed information about the process. It should be written in simplicity for better understanding by the donor. The donor must be voluntary, not forced, the consent must be taken in writing and the documents must be well protected. In this context, a detailed consent form for cadaver donation is structured. English version of the detailed consent form is presented in Supplement 1, and Turkish version is presented in Supplement 2.

\section{Discussion}

Physicians conduct their professional activities within the framework of laws and professional regulations. One of the professional activities of the anatomists is cadaver donation. In our country, body-organ and tissue donations are regulated by the law no. $2238 .^{[1]}$

As a part of our legal system, European Convention on Human Rights and Biomedicine and Law no. 2238 gives physicians responsibility for informing about any intervention in the field of health, including research. ${ }^{[1,6]}$

Recent High Court jurisprudence states that information in the consent form must be elaborated and detailed. Literature research revealed that good application examples involve detailed information about the donation process (from acceptance of the body to funeral procedures). We suggest that the following headings should be included in the donation form when the donors' opinions were taken into consideration:

The person who gives information should be a physician: The informing process must be done by a competent staff, preferably by a physician. In this way, the donor will be able to take accurate information about the processes and donor will not be hesitated. On the other hand, the donor must also be competent. Underage or donors with inadequate mental capacity should not be accepted. If the donor is dead, written consent of all legal heirs must be taken in terms of legal issues (this point should be well questioned for legal complications that may arise later).

The consent form must be clear and understandable: The processes to be performed must be expressed in detail. It must be avoided from medical terms or medical terms must be explained in a way that the donor can understand. In an earlier study, donors stated that they refused or hesitated donations not because they were against the donation, but due to lack of information they demanded. ${ }^{[7]}$

The relatives who are informed about the donation, relatives to whom the funeral will be delivered after the completion of the process must be recorded: A number of relatives should be informed about the donation. Thus, after the death of the donor, there will be no time loss during the transfer of the funeral to the institution. Also, a number of relatives should be recorded for the delivery of the funeral after completing use of cadaver.

The form should include information about the nature of dissections or scientific researchers: Cadavers are mainly used for medical education and scientific research. In the dissection of the cadaver for medical education, body cavities may be opened, organs or body parts may be removed. When the funeral is delivered, its integrity will be impaired. Scientific researches on cadavers may include surgical procedures, implantation applications, trauma exercises, disarticulations, imaging methods, histopathological, cytological or microbiological examinations. 
Donors must be voluntary and must consent to donation: Cadaver donation process should be conducted on volunteering and the donor should not be forced. ${ }^{[7]}$

There should not be any kind of interest between the institution and the donor or next-of-kins: In Turkey, tissue and organ trading is prohibited, thus cadaver donation should be made without any interest.

Donation-related records must be in hand-writing: In order to avoid legal problems, consent for donation should be written and witnessed. All the records should be well-kept.

The contact information of the institution should take place in the consent form: The communication information should be easily accessible. Donors or those seeking information should be able to access to anatomy department easily.

Use of cadavers is an indispensable part of medical education and cadaver donation process should be carried out carefully. Because a legal problem that may be experienced in this regard will affect the donations which are already low and inadequate.
We hope that this study will contribute to donation process and provide a detailed information on the consent forms for all anatomists and other medical staff.

\section{References}

1. Law No. 2238. Available at: http://www.mevzuat.gov.tr/Mevzuat Metin/1.5.2238.pdf

2. Cotter H. Increasing consent for organ donation: mandated choice, individual autonomy, and informed consent. Health Matrix Clevel 2011;21:599-626.

3. Oral T. Hekimin aydinlatma ve hastanin rizasini alma yukumu. Ankara Barosu Dergisi 2011;2:185-209.

4. Şimsek U. Sağlık hukukunda aydınlatılmış rıza. Dokuz Eylül Üniversitesi Hukuk Fakültesi Dergisi 2015;C16:3535-56.

5. Ipekyüz FY. Hekimin tazminat sorumluluğu. Dicle Üniversitesi Hukuk Fakültesi Dergisi 2015;20:19-61.

6. Council of Europe. Convention for the protection of human rights and dignity of the human being with regard to the application of biology and medicine: convention on human rights and biomedicine. Oviedo, 4.IV.1997. Available at: https://rm.coe.int/168007cf98.

7. McEwen PM. Valid informed consent: the key to increasing supply of organs for transplantation? Crit Care Resusc 2005;7:249.

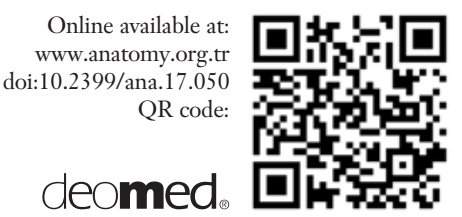

Correspondence to: Sedat Develi, MD
Department of Anatomy, Gülhane Faculty of Medicine,
University of Health Sciences, Ankara, Turkey
Phone: +90 5415272700
e-mail: drsedatdeveli@gmail.com
Conflict of interest statement: No conflicts declared.

This is an open access article distributed under the terms of the Creative Commons Attribution-NonCommercial-NoDerivs 3.0 Unported (CC BY-NCND3.0) Licence (http://creativecommons.org/licenses/by-nc-nd/3.0/) which permits unrestricted noncommercial use, distribution, and reproduction in any medium, provided the original work is properly cited. Please cite this article as: Develi S. A detailed cadaver donation form. Anatomy 2018;12(1):38-44.

Supplements to this article containing English and Turkish versions of the cadaver donation form are given on the following four pages. 
Supplement 1. English version of the detailed consent form for cadaver donation.

\section{CADAVER DONATION FORM}

This form consists of two parts.

Part One: General information on cadavers and donations

Part Two: Cadaver Donation Information

\section{GENERAL INFORMATION}

\begin{tabular}{|c|c|}
\hline What is a cadaver? & $\begin{array}{l}\text { It is a dead human body that has been specially treated to prevent its deterioration, is } \\
\text { used for training in anatomy class. }\end{array}$ \\
\hline $\begin{array}{l}\text { What is the cadaver used } \\
\text { for? }\end{array}$ & $\begin{array}{l}\text { It is used to teach the structure of the human body in student education, especially } \\
\text { medical education or other health sciences (dentistry, nursing, FTR, Health Vocational } \\
\text { Schools). It is also used in postgraduate training, scientific research, surgical } \\
\text { intervention studies. }\end{array}$ \\
\hline How is cadaver used? & $\begin{array}{l}\text { All anatomical structures are revealed by dissection in the direction of the relevant } \\
\text { course and/or researcher. The revealed structures are used for training and/or research } \\
\text { purposes. Both instructors and students continue to work with awareness of the value of } \\
\text { the sacrifices our donors. The care and respect required during these studies are } \\
\text { maintained and followed without any concessions. }\end{array}$ \\
\hline $\begin{array}{l}\text { Who can make cadaver } \\
\text { donation? }\end{array}$ & $\begin{array}{l}\text { Anyone who is not mentally ill od who is not under age can donate before two witnesses. } \\
\text { Persons who want to donate a deceased person as a cadaver may donate again in the } \\
\text { presence of two witnesses with the approval of all legal representatives. Cadaver } \\
\text { donation is acceptable for Islamic religion (Presidency of Religious Affairs) }\end{array}$ \\
\hline $\begin{array}{l}\text { How does the donation } \\
\text { process work? }\end{array}$ & $\begin{array}{l}\text { After the donor's death, the funeral is quickly transferred to the relevant Anatomy AD or } \\
\text { related institution's morg unit. It is subjected to a fixation process to stop the } \\
\text { deterioration. The funeral is then held in formaldehyde for about } 6 \text { months to complete } \\
\text { the fixation process. }\end{array}$ \\
\hline What is fixation? & $\begin{array}{l}\text { The cadaver is protected by using chemical fluids, so that the tissue properties remain } \\
\text { similar to that of living organisms. The aim here is to stop the deterioration of the } \\
\text { cadaver so that it can be examined for a long time. In Turkey, formaldehyde liquid is } \\
\text { generally used for this process. }\end{array}$ \\
\hline $\begin{array}{l}\text { What are Scientific } \\
\text { Researches? }\end{array}$ & $\begin{array}{l}\text { These are the studies for the development of medical science. Investigations using } \\
\text { cadavers include surgical procedures, implant procedures, trauma studies, } \\
\text { disarticulations, imaging methods, histopathological, cytological, biochemical, } \\
\text { microbiological examinations. }\end{array}$ \\
\hline \multirow{4}{*}{ Terminology } & Fixation (Old-style Embalming): Permanent medication to prevent deterioration \\
\hline & Dissection: Opening the cadaver by cutting to examine the internal structure. \\
\hline & Disarticulation: Separation of bones from joints \\
\hline & Extremity: Limb (arm or legs) \\
\hline
\end{tabular}

\section{CADAVER DONATION INFORMATION}

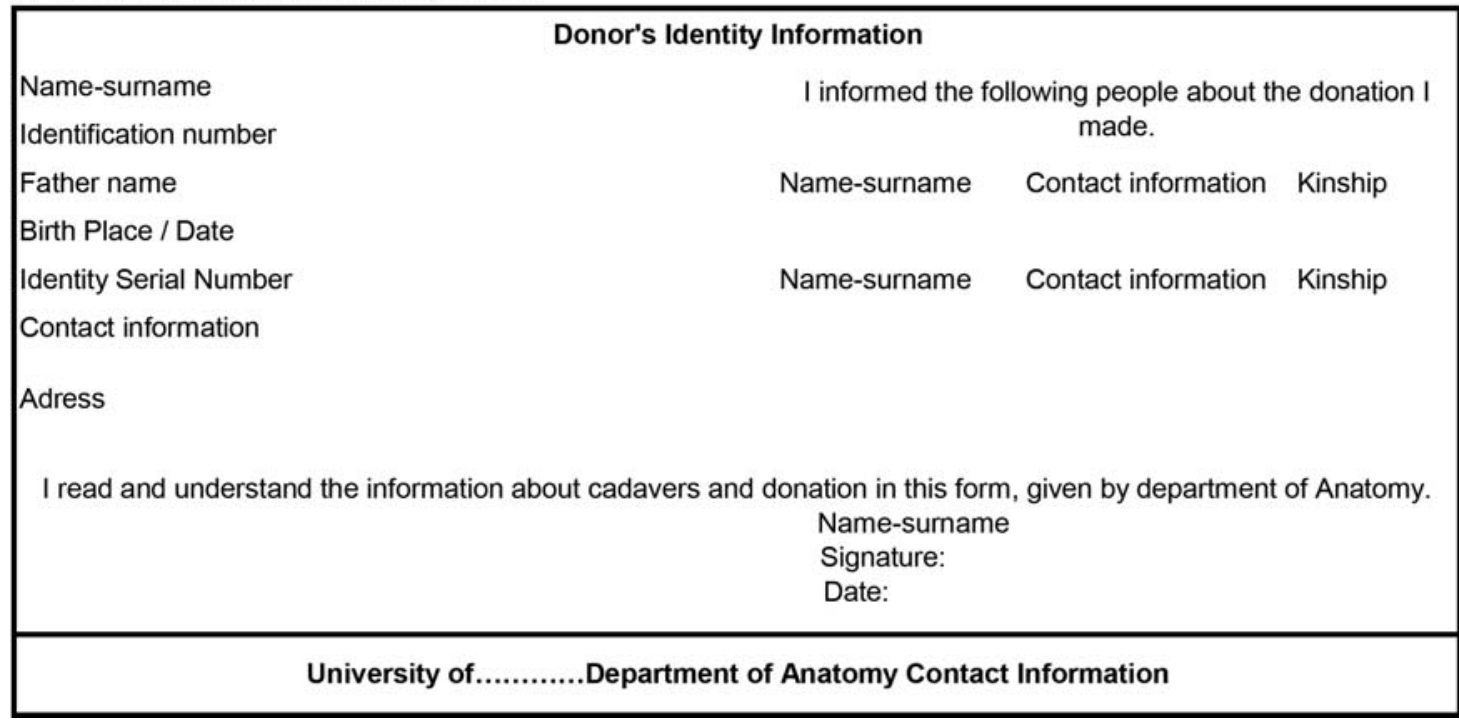


Supplement 1. [Continued] English version of the detailed consent form for cadaver donation.

CADAVER DONATION FORM

PLEASE READ CAREFULLY THE INFORMATION BELOW. ASK TO THE PHYSICIAN WHO IS INFORMING YOU FOR WHAT
YOU DO NOT UNDERSTAND.

I understand the following explanations as a condition for donation and funeral procedures

I make this donation voluntarily, without any coercion or restriction and without any financial interest.

Accepting of donation depends on the criteria specified by Department of Anatomy. The donation does not always mean that the body will be accepted as a cadaver. The donation can be refused for reasons such as not being suitable for fixation (the beginning of deterioration) or delays in transporting the funeral.

Fixation (embalming) will be done for protection to long term use of the cadaver. Detailed surgical procedures will be conducted for education and scientific studies. During these examinations, body organs can be removed or disarticulation can be performed for body parts such as extremities, head, spine. Tissue samples can be taken for histopathological examination. I allow to Department of Anatomy that part of my body to be kept indefinitely for educational and/or scientific purposes.

All or part of the donated cadaver can be moved for research purposes, such as training courses or radiological imaging in the institution or to another institution, with permission provided from the administration.

The cadaver will not be used for any purpose other than educational and scientific research. It will be protected with respect and care. It will not be exhibited in any way.

The tissues, organs, parts or all of the cadaver can be used unlimitedly in scientific research, student education or postgraduate training. Scientific publications (such as articles, case reports) or lecture presentation materials can be prepared with the data obtained as a result of researches on cadavers. For such academic studies, scientific publications or course presentations, photographs or videos may be taken by hiding the donor's identity. The donor's identity will not be shared with anyone under the responsibility of "Physician's keeping secrets of patients".

As a result of using the body as a cadaver, body integrity will be impaired. During the return of the body; the tissues and organs will not be complete due to the dissections made during educational activities or scientific researches.

\section{DONATION CERTIFICATE}

In the light of the information given and in the presence of witnesses, after my death I donate my body as cadaver to the Department of Anatomy of University, without any financial interest. Signature:

Purpose of use: Educational activities/Scientific Activities/In both educational and scientific activities Please indicate by handwriting:

Donation Time: 3 Years / Other / No time limit

Please indicate by handwriting:

Funeral procedures: After the use of my body as cadaver is completed;

1. I want my body to be delivered to my family.

The person i would like my body to be delivered to is;
Name-Surname:
Contact Information:
Kinship:
Name-Surname:
Contact Information:
Kinship:

2. I want to be buried in a graveyard which will be determined by the municipality. I want the funeral ceremony will be

done in accordance with ..... religion / I do not want funeral ceremony

Please indicate by handwriting:

\begin{tabular}{|llll|}
\hline Donor & Name-Surname & Signature & Date \\
Witness & Name-Surname & Signature & Date \\
Witness & Name-Surname & Signature & Date \\
Physician & Name-Surname & Signature & Date \\
\hline Donor's Medical Story (Optional): & Height: & Weight: \\
Profession: & Orthotics-Prosthetics: \\
Previous surgeries: & & \\
Other (if present): & & \\
\end{tabular}


Supplement 2. Turkish version of the detailed consent form for cadaver donation.

\section{KADAVRA BAĞIŞ FORMU}

Bu form iki kısımdan olușur.

Birinci Kısım: Kadavra ve bağı̧ konusunda genel bilgiler

İkinci Kısım: Kadavra Bağış Bilgileri

1. GENEL BILGILER

\begin{tabular}{|c|c|}
\hline Kadavra nedir? & $\begin{array}{l}\text { Anatomi dersinde eğitim amacıyla kullanılan, bozulmasını önlemek için özel işleme } \\
\text { tabi tutulmuş cansız insan vücududur. }\end{array}$ \\
\hline $\begin{array}{l}\text { Kadavra ne için } \\
\text { kullanılır? }\end{array}$ & $\begin{array}{l}\text { Başta tıp eğitimi olmak üzere, sağlık bilimlerinde (diş hekimliği, hemşirelik, FTR, } \\
\text { Sağlık Meslek Yüksekokulları gibi) öğrenci eğitiminde insan vücudunun yapısını } \\
\text { öğretmek amacıyla kullanılır. Mezuniyet sonrası eğitimlerde, bilimsel araştırmalarda, } \\
\text { cerrahi girişim çalışmalarında da kullanılır. }\end{array}$ \\
\hline Kadavra nasıl kullanılır? & $\begin{array}{l}\text { illgili dersin ve/veya araştırmanın konusu doğrultusunda, diseksiyon yapılarak tüm } \\
\text { anatomik yapılar ortaya konulur. Ortaya çıkarılan yapılar, eğitim ve/veya araştırma } \\
\text { amacılyla kullanıır. Gerek eğitmenler, gerek öğrenciler bağış̧ılarımızın değeri } \\
\text { ölçülemeyecek olan fedakarlıklarının farkında olarak çalışmalarını sürdürürler. Bu } \\
\text { çalışmalar esnasında gerekli olan özen ve saygı korunur ve hiç bir taviz verilmeden } \\
\text { takip edilir. }\end{array}$ \\
\hline Kimler kadavra olabilir? & $\begin{array}{l}\text { Akli melekeleri yerinde ve reşit olan herkes, iki şahit huzurunda bağışta bulunabilir. } \\
\text { Vefat etmiş bir yakınını kadavra olarak bağışlamak isteyen kişiler, tüm yasal vasilerin } \\
\text { onayı ile yine iki şahit huzurunda bağışta bulunabilir. Kadavra bağışı İslam dini } \\
\text { açısından caizdir (Diyanet İşleri Başkanlığı) }\end{array}$ \\
\hline Bağış süreci nasıl işler? & $\begin{array}{l}\text { Bağışçının vefatı sonrası cenaze, süratle ilgili Anatomi AD.'a ya da ilgili kurumun morg } \\
\text { ünitesine nakledilir. Ölü çürümesini durdurmak amacıyla cenaze fiksasyon işlemine } \\
\text { tabi tutulur. Cenaze daha sonra, yaklaşık } 6 \text { ay fiksasyon işleminin tamamlanması için } \\
\text { formaldehit isimli sıvı içerisinde bekletilir. }\end{array}$ \\
\hline Fiksasyon nedir? & $\begin{array}{l}\text { "Tespit" olarak da bilinir. Kadavranın kimyasal sıvılar kullanılarak, doku özelliklerinin } \\
\text { canlıdakine benzer şekilde kalması için korunmasıdır. Burada amaç, kadavranın uzun } \\
\text { süre incelenebilmesi için bozulmasını durdurmaktır. Türkiye'de genellikle bu işlem için } \\
\text { formaldehit sıvıSı kullanıır. }\end{array}$ \\
\hline $\begin{array}{l}\text { Bilimsel Araştırmalar } \\
\text { nedir? }\end{array}$ & $\begin{array}{l}\text { Tıp biliminin gelişimi için yapılan araştırmalardır. Kadavra kullanılarak yapılan } \\
\text { araştırmalar; cerrahi girişimleri, implant işlemlerini, travma çalışmalarını, } \\
\text { disartikülasyonları, görüntüleme yöntemlerini, histopatolojik, sitolojik, biokimyasal, } \\
\text { mikrobiyolojik incelemeler gibi yöntemleri kapsar. }\end{array}$ \\
\hline \multirow{4}{*}{ Terimler } & Fiksasyon (Eski dilde Tahnit): Bozulmaması için ölüyü ilaçlama \\
\hline & Diseksiyon: Kadavranın iç yapısını incelemek üzere kesip açma olayı. \\
\hline & Disartikülasyon: Kemiklerin eklem yerlerinden kesilerek ayrılması \\
\hline & Ekstremite: Uzuv (kol ya da bacaklar) \\
\hline
\end{tabular}

\section{KADAVRA BAĞıŞ BILGILERI}

\section{Bağışçının Kimlik Bilgileri}

Adı Soyadı

TC Kimlik No

Baba Adı

Doğum Yeri/Tarihi

TC Kimlik Seri No

iletişim Bilgileri

Adres
Yaptığım bağış hakkında şu kişileri bilgilendirdim.

$$
\text { Adı Soyadı İletişim Bilgileri Yakınlığı }
$$

Adı Soyadı İletişim Bilgileri Yakınlığı

Bu formda yer alan, Kadavra Bağışı ve Kullanımı hakkında tarafıma, Anatomi AD. Başkanlığınca verilen bilgileri okudum, anladım.

Adı Soyadı:

İmza:

Tarih:

Üniversitesi Anatomi AD. İletişim Bilgileri: 
Supplement 2. [Continued] Turkish version of the detailed consent form for cadaver donation.

KADAVRA BAĞIŞ FORMU

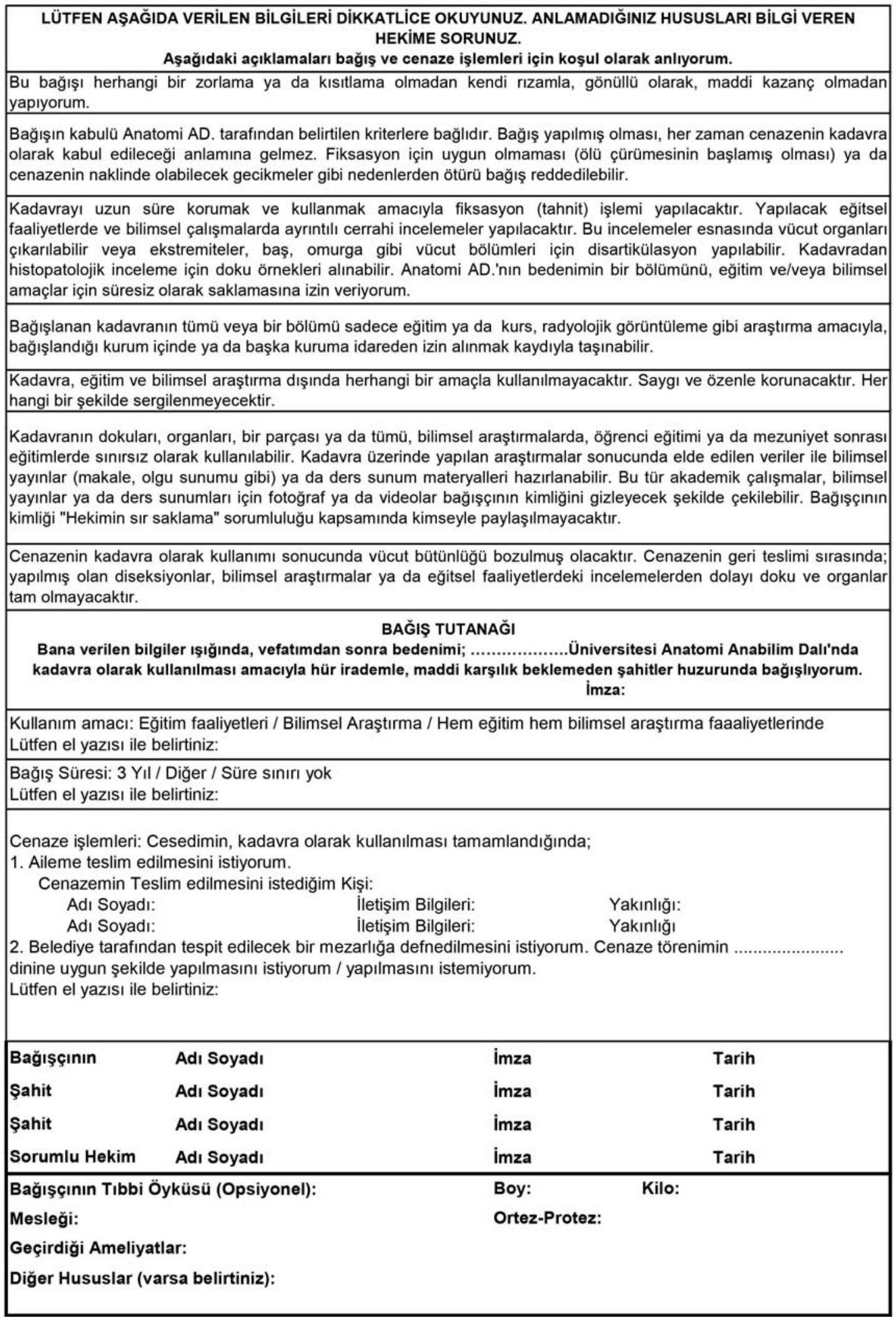

